\title{
BENCANA DAN INTEGRASI MASYARAKAT: SUATU KAJIAN TENTANG BAHAYA SERAM TAHUN 1899 DAN KAITANNYA DENGAN HUBUNGAN PELA AMAHAI DAN IHAMAHU
}

\author{
Disaster And Community Integration: \\ A Study on the "Bahaya Seram" of 1899 and Its Relationship With "Pela" Amahai \\ and Ihamahu
}

Samuel Michael Wattimury

Universitas Pattimura Ambon

Jalan Ir. M. Putuhena, Poka, Ambon 97233

E-mail: wattimurysamuel@gmail.com

\begin{abstract}
The background of this research is to explore the bahaya Seram disaster in 1899, seen from the historical trajectory of the earthquake and tsunami disaster in the Maluku islands, as the meeting point for the Indo-Australian Ocean plate with the Eurasian continental plate, and the impact of the bahaya Seram disaster in 1899 is the occurrence of community integration, namely the formation of a pela between Negeri Amahai on the island of Seram and Negeri Ihamahu on the island of Saparua.The research method used is a qualitative method with a descriptive approach. Data collection techniques used are literature, observation, interviews. Data analysis techniques use triangulation of data, theory and methodology.The result of this research is the discovery of the fact that there is integration in people's lives (Pela Amahai and Ihamahu relations), due to the earthquake and tsunami (bahaya Seram). The conclusion of this study is that there are important lessons that can be taken from the bahaya Seram disaster (mitigation, evacuation, etc.) and the relationship between the pela as a result of this disaster is still maintained today.
\end{abstract}

Keywords: disaster, community integration, pela.

\begin{abstract}
Abstrak
Latar belakang penelitian ini adalah untuk mengeksplor bencana bahaya Seram tahun 1899 dilihat dari lintasan sejarah bencana gempa bumi dan tsunami dikepulauan Maluku, sebagai tempat bertemunya lempeng Samudera Indo-Australia dengan lempeng Benua Eurasia. Dampak dari bencana bahaya Seram tahun 1899 adalah terjadinya integrasi masyarakat yaitu terbentuknya pela antara Negeri Amahai dipulau Seram dan Negeri Ihamahu dipulau Saparua. Metode penelitian yang digunakan adalah metode kualitatif dengan pendekatan deskriptif. Teknik pengumpulan data yang digunakan adalah kepustakaan, observasi, wawancara. Teknik analisis data menggunakan triangulasi terhadap data, teori dan metodologi. Hasil dari penelitian ini adalah ditemukannya fakta bahwa terjadinya integrasi dalam kehidupan masyarakat (hubungan pela Amahai dan Ihamahu), akibat bencana gempa bumi dan tsunami (bahaya Seram). Kesimpulan penelitian ini adalah adanya pelajaran penting yang dapat diambil dari bencana bahaya Seram (mitigasi, evakuasi, dll) dan juga hubungan pela akibat bencana ini masih terpelihara hingga sekarang.
\end{abstract}

Kata kunci: bencana, integrasi masyarakat, pela. 


\section{PENDAHULUAN}

\section{Anugerah dan bencana adalah kehendakNya}

Kita mesti tabah menjalani

Hanya cambuk kecil agar kita sadar

Adalah Dia di atas segalanya...

(Karya: Ebiet G. Ade)

Ini adalah sebagian dari lirik lagu yang mengakui bahwa dalam kehidupan kita terdiri dari dua unsur utama kehidupan itu sendiri yaitu anugrah atau kebahagian dan juga bencana atau kesedihan. Hal ini bukan saja dihadapi oleh individu manusia saja, namun sebuah negara yang besar seperti Indonesia juga mengalami kedua hal tersebut. Bisakah kita membayangkan betapa banyaknya anugerah yang diberikan Tuhan Yang Maha Esa kepada Indonesia sebagai sebuah negara kepulauan terbesar di dunia, yang kaya akan sumberdaya hayati dan non hayati. Tidaklah juga mengherankan jika julukan "zamrut khatulistiwa" disematkan pada negara yang berbentuk republik ini. Secara geologis kepulauan Indonesia berada pada jalur penunjaman lempeng Samudra Indo-Australia dengan lempeng Benua Eurasia. Penunjaman ini memberikan keuntungan bahwa tanah disekitarnya akan menjadi subur dan produktif, namun akibat lainnya menjadikan Indonesia memiliki banyak gunung api yang masih aktif yang berakibat pada bahaya letusan gunung api serta banjir lahar dingin terutama pada musim hujan dan gempa bumi baik gempa vulkanik maupun gempa tektonik. Sebagian besar jalur gempa bumi tersebut berada di laut sehingga sangat berpotensi menimbulkan bencana tsunami, hal ini juga harus diwaspadai.

Beberapa penelitian terdahulu telah menjelaskan banyak hal tentang bencana di Indonesia, seperti Sartono Kartodirjo dalam bukunya "Pemberontakan Petani Banten 1888", yang salah satu penyebabnya adalah penyakit sosial yang timbul akibat bencana letusan gunung Krakatau tahun 18883, ada juga buku yang ditulis Apridar tentang "Tsunami Aceh, Azab atau Bencana?" yang mengupas tentang peristiwa Tsunami Aceh tahun 2004, namun dalam penelitian ini penulis lebih tertarik untuk mengobservasi timbulnya integrasi masyarakat akibat dari suatu peristiwa bencana, hal ini terjadi dikepulauan Maluku yakni integrasi masyarakat yang terjalin antara Negeri ${ }^{1}$ Ihamahu di Pulau Saparua dan Negeri Amahai di Pulau Seram, uniknya integrasi masyarakat ini disebabkan oleh bencana tsunami yang lebih di kenal dengan nama bahaya seram oleh masyarakat Maluku, yang terjadi di Pulau Seram pada tanggal 29 September 1899 dan memakan korban jiwa serta harta benda dari kedua belah pihak, untuk itu permasalahan yang menjadi fokus dalam penelitian ini adalah bagaimana proses intergrasi masyarakat, dalam bentuk hubungan pela antara negeri Amahai dan Ihamahu akibat bencana bahaya Seram yang terjadi pada tahun 1899 ?.

Dengan mengunakan metode penelitian kualitatif deskriptif, yaitu penelitian yang menghasilkan data deskriptif, sehingga berhasil menjawab tujuan penuliasan ini, yaitu untuk mengetahui tentang fakta bahwa terjadinya integrasi dalam kehidupan masyarakat

\footnotetext{
${ }^{1}$ Negeri adalah suatu bentuk komunitas masyarakat, sama halnya dengan Desadipulau Jawa. Negeri dipimpin oleh seorang raja.
} 
(hubungan pela Amahai dan Ihamahu), akibat bencana gempa bumi dan tsunami (bahaya Seram). Teknik pengumpulan data yang digunakan adalah kepustakaan, observasi, wawancara. Teknik analisis data menggunakan triangulasi data, setelah itu dilakukan proses seleksi dan penyederhanaan data, sehingga menjadi akurat untuk kemudian dilakukan penarikan kesimpulan. Mengakhiri proses tersebut, maka langkah yang terakhir dalam proses analisa data yaitu penyajian hasil penelitian secara ilmiah (Moleong, 2002).

\section{PEMBAHASAN}

\section{Peristiwa Bencana (Bahaya Seram), Dalam Lintasan Sejarah}

Bencana adalah suatu peristiwa tidak dapat diprediksi dan sampai saat ini tidak ada seorang manusiapun yang dapat meramal secara pasti kapan bencana itu terjadi. Menurut Undang-Undang No. 24 Tahun 2007 , bencana adalah peristiwa atau rangkaian peristiwa yang mengancam dan mengganggu kehidupan dan penghidupan masyarakat yang disebabkan, baik oleh faktor alam dan atau faktor non alam maupun faktor manusia sehingga mengakibatkan timbulnya korban jiwa manusia, kerusakan lingkungan, kerugian harta benda, dan dampak psikologis. Lebih lanjut dalam Undang-Undang No. 24 Tahun 2007, jenis-jenis bencana antara lain: 1. bencana alam; 2. bencana non alam; 3. bencana sosial, maka bencana gempa bumi yang berakibat terjadinya gelombang tsumani di Pulau Seram pada tahun 1899, dimasukan kedalam kategori bencana alam atau natural disaster.

Berbicara mengenai bencana, maka kita akan berbicara tentang suatu peristiwa atau kejadian. Peristiwa atau kejadian yang terjadi dimasa lampau adalah sebuah sejarah yang benar-benar terjadi atau berdasarkan fakta, yang bersifat abadi dan unik. (Binnendyk \& Pusparani, 2015). Oleh karena itu, sejarah menjadi penting dalam hidup manusia sebagai pengingat dan pembentuk jati diri. Namun realitas menunjukan bahwa tidak sedikit masa lalu yang menjadi perdebatan antar kelompok masyarakat, hal ini ditandai dengan adanya pengakuan dari sekelompok masyarakat terhadap suatu peristiwa sejarah, tokoh sejarah, monument bersejarah maupun suatu tempat bersejarah. Oleh karena itu, seharusnya peristiwa masa lalu harus direkonstruksi sebagaimana dikemukakan oleh Kuntowijoyo (1995), bahwa sejarah sebagai rekonstruksi masa lalu artinya apa yang telah terjadi dalam kaitannya dengan manusia dan tindakan manusia direkonstruksi dalam bentuk kisah sejarah, karena itu sebelum kita lebih jauh melihat tentang dampak dari peristiwa bencana gempa bumi yang berakibat terjadinya gelombang tsumani di Pulau Seram pada tahun 1899, alangkah lebih baiknya kita pelajari dahulu sejarah dari peristiwa bencana tersebut.

Bahaya Seram adalah julukan yang diberikan oleh masyarakat Maluku terhadap peristiwa bencana gempa bumi dengan magnitudo 7,8 SR, berakibat terjadinya gelombang tsumani setinggi 10 meter, di Pulau Seram yang terjadi pada tanggal 29 September 1899, julukan ini diberikan karena peristiwa ini membahayakan kehidupan penduduk di daerah Pulau Seram sendiri (masyarakat negeri-negeri disepanjang Tanjung 
Koako sampai dengan Tanjung Elpaputih). Secara geografis keberadaan Negeri Amahai sebelum terjadinya peristiwa bahaya Seram, tidak seperti keberadaan Negeri Amahai yang sekarang ini. Daluhu, Amahai dilindungi oleh Tanjung Kuako yang pada waktu itu menjulang jauh ke laut, serta hampir mendekati Tanjung Elpaputih. Kedudukan kedua tanjung yang saling menjorok ke laut tersebut dengan sendirinya membentuk sebuah teluk yang lebih dikenal dengan sebutan teluk Elpaputih, namun setelah terjadinya peristiwa bahaya Seram posisi kedua tanjung yang menjorok kelaut itu sebahagiannya hilang akibat ditenggelamkan oleh gelombang air laut. ${ }^{2}$

Tidak dapat disangkali pada masa itu seluruh wilayah negara Indonesia masih dikuasai oleh Belanda, termasuk didalamnya Negeri Amahai yang pada saat itu menjadi Ibu Kota Onderafdeling Seram Selatan dan dikepalai oleh seorang controler atau pejabat Belanda bernama Van Genth, sedangkan yang menjadi pemimpin Negeri Amahai pada saat itu ialah Raja Welhelem Hallatu, dengan pendeta jemaat ialah Pendeta Gaspersz, yang menjabat kepala sekolah rakyat saat itu adalah Guru Tamaela. Penduduk Negeri Amahai ditahun 1899 menurut beberapa tulisan terdaftar 2.379 jiwa.Seperti daerah jajahan lainnya, setiap tanggal 31 Agustus masyarakat Amahai, diwajibkan untuk merayakan ulang tahun Ratu Kerajaan Belanda yakni Ratu Welhelmina, perayaan ulang tahun tersebut berlangsung dengan sangat meriah. Kegembiraan masyarkaat Amahai masih terus berlanjut, dengan peristiwa kedatangan saudara-saudara dari Negeri Ihamahu yang datang untuk meramu kayu dalam rangka pembangunan gedung Gereja Ebenheizer di Negeri Ihamahu. Ditengah-tengah sukacita tersebut, masyarakat digemparkan dengan berita yang sangat menghebohkan melalui mimpi seorang pemuda yang berprofesi sebagai seorang pembantu dari Bapak Lasamahu, ${ }^{3}$ bernama Welhelmus Pulawang yang adalah seorang yang berasal dari keturunan Nuaulu yang baru saja memeluk ajaran agama Kristen Protestan.

Pada malam, tanggal 19 September 1899 Welhelmus Pulawang bermimpi, dalam tidurnya ia melihat seorang Malaikat datang dan memberitahukan kepadanya bahwa pada malam tanggal 29 September 1899 pukul 02.00 WIT (jam 2 dini hari) akan terjadi bencana alam yang maha dahsyat berupa air laut akan turun naik (tsunami) serta menutupi sebagian negeri dan perkampungan. Dalam mimpi itu pula ia menerima petunjuk untuk menyelamatkan diri, bahwa ketika peristiwa itu terjadi penduduk harus melarikan diri ke daerah Laalodan terus berlari hingga Kupapoyowoni ${ }^{4}$ dan tidak boleh melewati Kali Wairano. Keesokan harinya Welhelmus menceritakan apa yang dialaminya dalam mimpi kepada setiap orang yang dijumpainya, maka tersiarlah kabar berita mengenai mimpinya itu. Mimpi Welhelmus Pulawang membuat gempar dan menimbulkan kepanikan yang luar biasa ditengah-tengah masyarakat. Kehebohan kabar dari mimpi Welhelmus tersebut terdengar sampai pada Controler tuan Van Genth, untuk mengurangi dan menghindari kepanikan masyarakat yang lebih besar maka Van Genth memerintahkan penahanan

\footnotetext{
${ }^{2}$ Wawancara dengan Bapak E. Wattimury, 01 February 2017.

${ }^{3}$ Lasamahu bekerja sebagai seorangpendeta.

${ }^{4}$ Laalo dan Kupapoyowoni adalah daerah hutan yang terletak disebelah belakang dari negeriAmahai, kedua daerah tersebut merupakan daerah dataran yang lebih tinggi dari negeri Amahai.
} 
terhadap Welhelmus Pulawang dan jika kabar berita yang disampaikan tidak benar terjadi, maka Welhelmus akan dijatuhi hukuman yang berat. Penahanan terhadap Welhelmus sesungguhnya merupakan suatu cara untuk meredam kepanikan yang lebih besar ditengah-tengah masyarakat. ${ }^{5}$

Menurut penuturan sejarah lisan berdasarkan hasil wawancara dan catatan ringkas peristiwa bahaya Seram, bahwa pada sehari sebelum kejadian itu terjadi suasana alam masyarakat Negeri Amahai terasa berbeda dengan hari-hari sebelumnya, matahari pagi pada saat itu bersinar tidak cerah, pada siang hari matahari bersinar remang-remang dan tidak menimbulkan rasa panas seperti hari biasanya, di sore hari matahari terbenam di ufuk barat dengan sinar yang berwarna kemerah-merahan tidak seperti biasanya, kehidupan manusia mulai larut di tengah kesunyian malam. Manusia mulai mencari tempat peraduan untuk mengistirahatkan tubuh dalam kelelahan yang dijalani dalam satu hari aktifitasnya. Kesunyian malam ditandai dengan lolongan anjing seakan bersedih menghentar waktu yang terus berjalan. Suasana semakin mencekam membuat mereka yang masih terjaga dari tidurnya digelisahkan oleh kesunyian malam yang semakin menakutkan itu. ${ }^{6}$ Hari semakin larut, waktu pada jam dinding menunjukan pukul 01.40 menit terdengar bunyi dentuman yang maha dahsyat disertai dengan getaran (goncangan) tanah membuat mereka yang masih terjaga menjadi kaget dan panik serta mempersiapkan diri untuk menyelamatkan diri, sedangkan mereka yang tertidur menjadi kaget serta sebagian masih tetap terlelap dalam tidurya.

Goncangan tanah yang maha dasyat serta dentuman yang semakin keras kembali terjadi disertai dengan naiknya tiga buah gelombang besar dari arah laut yang datang secara berturut-turut memutus dan melewati Tanjung Kuako yang selama ini menjadi pelindung serta kebanggaan masyarakat negeri. Gelombang tsunami yang disebabkan gempa itu datang menerjang Teluk Elpaputih dan memporak-porandakan pemukiman masyarakat dan sebagian dari Teluk Elpaputih dan Tanjung Kuako masuk kedalam laut akibat terjadi patahan yang ditimbulkan gempa. Masyarakat yang menyelamatkan diri melewati Kali Wairano, semuanya tewas karena terhempas oleh gelombang besar yang datang, sebagian tergantung pada dahan-dahan pohon, sebagiannya lagi terseret air yang surut kelaut sehingga jasad mereka tidak ditemukan lagi.

Sedangkan yang menyelamatkan diri dengan berlari ke daerah Laalo dan terus ke Kupapoyowoni, mereka memperoleh kesempatan untuk hidup dan menceritakan kepedihan dan pengalaman pahit itu bagi generasi sepanjang masa. Matahari 30 September 1899, keluar dari balik gunung Kerulaya sebagai tanda bahwa kehidupan ini akan terus berjalan mereka yang masih diberikan keberuntungan untuk hidup turun ke negeri dan mengamati serta menyaksikan perbuatan alam yang maha dahsyat itu. Di tengah penderitaan dan kepedihan yang mendalam itu, masyarakat bergotong royong untuk mencari orang-orang yang hilang serta membersihkan negeri yang telah porakporanda akibat hantaman gelombang tsunami yang maha dahsyat itu. Berita mengenai

\footnotetext{
${ }^{5}$ Wawancara dengan Bapak S.Lernaya, 02 Februari 2017.

${ }^{6}$ Wawancara dengan Bapak E. C. Lokollo, 03 Februari 2017.
} 
bencana yang menimpa masyarakat Amahai serta Negeri-Negeri yang ada di pesisir Pulau Seram itu tersebar kemana-mana hingga sampai pada pimpinan Pemerintah Belanda di Ambon, maka dikirimlah bantuan untuk melayani korban bencana serta bantuan makanan dan lain-lain.

Kehadiran masyarakat dari Negeri Ihamahu yang awalnya disambut dengan suasana kegembiraan dan sukacita berganti dengan suasana sedih dan dukacita, ketika Pada tanggal 30 September masyarakat Ihamahu yang pulang ke Negerinya dengan membawa korban bencana tersebut. Dari hasil wawancara yang dilakukan diperoleh masyarakat Ihamahu yang meninggal dan luka-luka berjumlah 61 orang termasuk raja negerinya. Dengan menggunakan kapal milik Belanda rombongan dari Ihamahu berangkat menuju kampung halamannya diiringi ratap tangis serta duka yang mendalam akibat peristiwa alam yang terjadi.

Bukti mengenai peristiwa bahaya Seram tersebut hingga kini dapat kita jumpai di Negeri Amahai dengan tanda dibangunnya tugu peringatan bahaya Seram, di Negeri Amahai dibangun pada daerah Wairano tempat batas air laut yang naik hingga kedaratan, peringatan kepada mereka yang banyak meninggal dunia di tempat ini, selain itu tugu ini juga menjadi peringatan akan hubungan pela antara Negeri Amahai dan Negeri Ihamahu.

Selain itu, menyangkut kenangan pahit dalam peristiwa yang menyedihkan serta dukacita bagi masyarakat Amahai melalui perisitiwa bahaya Seram 29 September 1899 tersebut juga dilukiskan dalam sebuah syair lagu berikut ini:

Adalah peristiwa diakhir September 1899

Tak seorang pun tau, semua kan terjadi

Bencana alam ini

Jeritan terdengar disana-sini

Dimana ayah, ibu, dan sanak saudara

Hanyalah Tuhan yang tau segalanya

Kita yang tercelah, kita yang tersiksa

Kini menyatu hati

Marilah kita pupuk rasa saling cinta

Didalam pela kita sama satu gandong

Ingat janji Upu Ama dari dulu kala

Dan jangan kita lupakan sumpah kita ${ }^{7}$

Peringatan peristiwa bahaya Seram tersebut hingga kini masih dilaksanakan oleh masyarakat Amahai dengan melaksankan ibadah dan doa untuk memperingati terjadinya peristiwa tersebut setiap tanggal 29 September tahun berjalan. Masyarakat Amahai yang ikut dalam acara tersebut menggunakan busana berwarna hitam yang melambangkan dukacita yang mendalam atas peristiwa tersebut. Dalam ibadah itu juga, masyarakat Amahai mensyukuri kasih Tuhan yang besar atas penyertaan dan perlindungan-Nya bagi masyarakat Amahai yang selamat, sehingga kehidupan generasi anak cucu masyarakat Amahai masih ada hingga saat ini, selain itu peringatan peristiwa bahaya Seram tersebut

\footnotetext{
${ }^{7}$ Wawancara dengan Bapak T. Wattimury, 04 Januari 2017
} 
mengandung suatu harapan bahwa peristiwa itu tidak akan terulang lagi bagi generasi yang sekarang. Dari narasi sejarah mengenai bencana gempa bumi yang berakibat terjadinya gelombang tsumani di Pulau Seram pada tahun 1899, diatas ada beberapa hal penting, yang perlu digarisbawahi mengenai kenapa kita harus belajar dari peristiwa masa lalu atau sejarah tersebut.

Pertama, sejarah mengajarkan kita untuk mengetahui dan menyingkap tabir peristiwa besar (Notosusanto, 1979) yaitu bahaya seram yang terjadi di Negeri Amahai pada 29 September 1899, serta dampak positif dan negatif, melalui monumen atau tugu peringatan suatu peristiwa. Serta tuturan sejarah lisan yang disampaikan secara turun temurun dari generasi sebelumnya. Kedua, sejarah sebagai pengingat dimana semua peristiwa yang terjadi dimasa lampau, mengenai baik dan buruknya peristiwa itu sejarahlah yang menjadi alarm kehidupan.Ini bertujuan agar generasi muda jangan sampai melupakan peristiwa yang berdampak besar dalam kehidupan masyarakat Negeri Amahai tersebut. Selain itu peringatan akan peristiwa bahaya seram ini memiliki peranan penting sebagai pengalaman yang bisa menjadi suatu pedoman atau pegangan hidup bagi pada masyarakat Negeri Amahai dimasa sekarang dan masa depan dalam mengahadapi bencana alam serupa. Ketiga, peristiwa sejarah menjadi pelajaran penting dikeranakan peristiwa masa lalu berkaitan erat dengan peristiwa setelahnya. Oleh karena itu, sejarah dapat digunakan sebagai modal bertindak dimasa kini dan menjadi acuan untuk perencanaan masa yang akan datang, karena sejarah masa lalu adalah pelajaran yang sangat berharga peristiwa yang baik kita teladani, kegagalan dapat kita hindari (Kartodirdjo, 1994). Hal yang sama pun dapat kita ambil dari peristiwa bahaya seram yang terjadi di Negeri Amahai pada 29 September 1899, yang mana kita dapat melihat tanda-tanda alam sebelum peristiwa mengerikan itu terjadi, ataupun pola perilaku hewan yang berbeda yang diceritakan melalui tuturan sejarah lisan, menjadi penanda atau alarm bagi masyarakat Negeri Amahai dalam melakukan mitigasi pada bencana yang sama.

Sayangnya di Maluku pada umumnya dan Pulau Seram khusunya yang merupakan daerah rawan gempa dan tsunami, jarang untuk mendapatkan sosialisasi mitigasi bencana. Lebih parahnya lagi di daerah Maluku secara keseluruhan tidak ada mata pelajaran tentang mitigasi bencana pada kurikulum pendidikan, padahal masyarakatnya senantiasa hidup didalam ancaman gempa bumi dan tsunami. Hal inilah yang membuat banyak orang yang kalang kabut jika terjadi peristiwa alamini, dan berdampak juga pada banyaknya jumlah korban jiwa. Keempat, belajar dari sejarah menjadikan kita bijaksana, history makes man wise dikarenakan dapat menyikapi persoalan masa kini dengan bercermin pada persitiwa masa lalu (Notosusanto, 1979). Sebagai sang guru kehidupan, maka sejarah harus menjadi pelajaran dalam menatap hari esok yang lebih baik, dengan belajar dari peristiwa masa lalu atau sejarah itu sendiri.

\section{Pela Amahai dan Ihamahu (Integrasi Masyarakat, Dampak Bencana Bahaya Seram)}

Bagai dua sisi mata uang yang tidak dapat dilepas-pisahkan, maka suatu peristiwa bencana juga memiliki dampak negatif dan juga dampak positif, demikian juga dengan 
bencana bahaya Seram. Selain berdampak pada jatuhnya korban jiwa dan harta benda, tetapi juga memiliki dampak positif yaitu adanya integrasi masyarakat antara Negeri Amahai di pulau Seram dengan Negeri Ihamahu di Pulau Saparua, integrasi masyarakat itu disebut juga pela.

Integrasi sosial dalam sebuah masyarakat mensyaratkan tiga hal. Pertama, adanya kesepakatan dari sebagian besar anggotanya terhadap nilai-nilai sosial tertentu yang bersifat fundamental dan krusial. Kedua, sebagian terhimpun dalam berbagai unit sosial dan saling mengawasi dalam aspek-aspek sosial yang potensial. Hal ini untuk menjaga terjadinya dominasi dan penguasaan dari kelompok mayoritas atas minoritas. Ketiga, terjadi saling ketergantungan diantara kelompok-kelompok sosial yang terhimpun di dalam suatu masyarakat untuk pemenuhan kebutuhan ekonomi dan sosial secara menyeluruh (Parekh, 2008).

Di Maluku salah satu bentuk integrasi masyarakat sekaligus kearifan lokal yang dimiliki masyarakatnya dan terus dipelihara hingga dewasa ini adalah hubungan pela yang telah ada jauh sebelum zaman penjajahan dan merupakan hasil kebudayaan asli dari para leluhur. Pela merupakan salah satu bentuk integrasi sosial kemasyarakatan yang ada di Maluku, yang didasarkan atas sebuah peristiwa yang berdampak pada beberapa negeri yang kemudian mengangkat sumpah (perjanjian tidak tertulis) dan janji, serta disokong oleh kutukan yang mengerikan bagi siapapun yang melanggarnya. Uniknya, di daerah Maluku hubungan integrasi masyarakat dalam bentuk pela ini, tidaklah didasari oleh salah satu faktor penyebab saja, tetapi lebih dari satu faktor. Misalkan,Pela yang timbul akibat cinta muda-mudi (Negeri Latuhalat dan Negeri Allang dipulau Ambon). Pela yang timbul akibat perang (Negeri Halong dan Negeri Hitu dipulau Ambon). Pela yang timbul akibat bencana (Negeri Passo dan Negeri Batu Merah dipulau Ambon). Pela yang timbul akibat pemberian bantuan (Negeri Hative Besar dan Negeri Nusaniwe dipulau Ambon). Pela juga ditimbulkan akibat adanya hubungan ipar (Negeri Hative Besar dan Negeri Eri) yang dikenal dengan sebutan Pela Manuwei atau Pela Konyadu. Dan hubungan pela yang timbul karna berbagai faktor penyebab lainnya.

Menurut (Pattikayhattu, 2005) yang adalah seorang sejarawan Maluku, mengklasifikasi hubungan pela kedalam beberapa jenis, yaitu Pela keras bermula karena adanya peristiwa besar tertentu, biasanya berkaitan dengan perang, seperti pertumpahan darah, pertempuran yang tidak berakhir, atau juga karena bencana dan pemberian bantuan luar biasa yang diberikan oleh suatu negeri kepada negeri yang lain. Pela gandong ${ }^{8}$ atau bungsu didasarkan pada ikatan keturunan keluarga (atau perasaan memiliki sebagai sebuah keluarga kandung/persaudaraan adik dan kakak), yaitu satu atau beberapa suku yang memiliki marga dibeberapa negeri berbeda mengakui memiliki leluhur yang sama. Pela tempat sirih, dihasilkan setelah peristiwa kecil seperti untuk mendamaikan pertikaian atau setelah negeri memberi bantuan kepada negeri lain. Pela juga diartikan sebagai pejanjian untuk saling mengasihi seperti saudara kandung (Lokollo, 1997), sementara menurut hemat penulis pela juga dapat diklasifikasikan kedalam pembabakan

${ }^{8}$ Gandong berasal dari bahasa Ambon Melayu yang berarti kandung atau rahim. 
waktu sejarah yaitu, Pela sebelum Maluku melakukan kontak dengan dunia luar atau penjajahan, (Negeri Hattu dan Negeri Wakasihu dipulau Ambon). Pela saat berlangsungnya kontak dengan dunia luar atau karna perang melawan penjajahan, (Negeri Allang dipulau Ambon dan Negeri Piru dipulau Seramakibat keterlibatan penduduk Negeri Allang membantu Negeri Piru dalam Perang Hongi). Pela setelah kontak dengan dunia luar atau penjajahan ataupun sesudah zaman kemerdekaan, (Negeri Galala dan Negeri Hitu lama dipulau Ambon pada tahun 1959 yang mana Negeri Hitu Lama memberi perahu belang kepada Negeri Galala secara gratis dalam mengikuti perlombaan "Arumbae Manggurebe”). Pela di zaman dewasa ini, hubungan kerjasama antar pemerintah sebagaimana dilakukan oleh pemerintah Australia dengan pemerintah kota Ambon dengan melaksanakan perayaan tahunan Ambon Darwin (Pattiasina, 2019).

Sebelum kita mengkasifikasi hubungan pela antara Negeri Amahai dan Negeri Ihamahu, kita lihat narasi tentang terbentuknya hubungan pela yang berakibat pada terjadinya intergrasi masyarakat akibat bencana tersebut. Terjadinya pela antara Negeri Ihamahu di Saparua dan NegeriAmahai di Pulau Seram, berawal dari pembangunan gedung Gereja di Negeri Ihamahu. Pada tanggal 11 April 1890, di Negeri Amahai dilakukan musyawarah antar dua negeri. Pemerintah Negeri Amahai dengan sukacita menyambut pemerintah dan rakyat Ihamahu dengan ikatan pelamaka tanggal 13 April 1890, dengan dihadiri masyarakat Amahai dan utusan masyarakat Ihamahu, dikukuhkanlah ikatan pela, yakni pela tempatsirih. Hubungan pela ini menjadi lebih nyata, terjadi pada saat meramu kayu besi untuk keempat kalinya, dimana banyak sekali orang Ihamahu yang datang untuk meramu kayu besi disambut dengan sukacita oleh masyarakat Amahai selayaknya hidup orang berpela pada 27 September 1899, Wilhelem Lilipaly dan 80 orang laki-laki dari Negeri Ihamahu telah berada di Amahai dan telah mengerjakan kayu besi untuk dibawa ke Ihamahu. Namun malang tidak dapat ditolak, karena pada 29 September 1899, terjadi gempa besar yang memporak-porandakan Negeri di kawasan tersebut, dan juga merenggut nyawa 60 orang lhamahu termasuk Wilhelem Lilipaly, Raja Ihamahu. Hal ini menyebabkan terjadinya saling tuding menuding antara orang Amahai dan Ihamahu yang menyebabkan hubungan pela antara Amahai dan Ihamahu menjadi renggang.

Setelah Johanes Lilipaly diangkat sebagai Raja Ihamahu tahun 1923, bersama Abraham Halatu Raja Amahai, dengan dibekali semangat orang berpela, tanggal 25 Oktober 1924, pada malam hari di Ihamahu berlangsung rapat dalam rangka panas pela 9 kedua Negeri, maka ikatan tersebut kembali dikuatkan. Masing-masing pihak merasa menjadi saudara kandung dengan akar pela tidak boleh ada perkawinan antara kedua negeri tersebut. Dengan demikian, pela tampa siri berubah menjadi pela gandong atau bungsu, keputusan tersebut dikukuhkan pada hari Minggu, 26 Oktober 1924, dan sejak itu orang Ihamahu dan Amahai merasa menjadi satu. Dengan ikrar Sei Hale Hatu, Hatu Hale Ei, Sei Risa Sou, Sou Risa Ei, yang dalam bahasa Melayu Ambon memiliki arti Sapa

\footnotetext{
${ }^{9}$ Panas Pela adalah suatu bentuk perayaan antara negeri-negeri yang berpela untuk menghangatkan kembali hubungan Pela tersebut.
} 
Bale Batu, Batu Bale Dia, Sapa Langgar Janji, Janji Langgar Dia. ${ }^{10}$ Untuk saling mengingatkan kedua negeri akan hubungan pela tersebut, maka masing-masing memberikan kepada saudaranya suatu tanda antara lain, satu set Totobuang ${ }^{11}$ dan dua bodi ikan (kapal penangkap ikan) serta sebuah gong khusus yang disebut Gong Matapela. Hubungan ini terus terjalin hingga kini dan selamanya, hubungan pela kedua negeri ini juga dituangkan dalam bentuk prasasti di atas batu pualam.

Dari beberapa klasifikasi pela diatas maka, hubungan pela antara Negeri Amahai dan Negeri Ihamahu adalah hubungan pela yang timbul akibat suatu bencana gempa dan tsunami atau bahaya Seram. Selanjutnya, bentuk pela yang antara kedua negeri inipun berubah hal ini dikarenakan, pada awalnya kedua negeri ini menganut bentuk pela tempat siri (sebagai hasil Negeri Amahai yang memberi bantuan kayu untuk pembangunan gedung gereja Negeri Thamahu) berubah menjadi bentuk pela gandong atau bungsu, yang diakibatkan banyaknya korban jiwa yang jatuh dari kedua belah pihak, dan memiliki perasaan senasib karena bencana alam tersebut. Hubungan pela ini timbul saat berlangsungnya kontak dengan dunia luar (Belanda) ini dikarenakan bencana alam yang menyebabkan terjadinya hubungan pela ini terjadi pada tahun 1899 pada masa penjajahan Belanda di Nusantara, dan setelah masyarakat negeri merayakan hari ulang tahun Ratu Welhelmina, Ratu Kerajaan Belanda.

\section{SIMPULAN}

Berdasarkan permasalaha yang diangkat dalam penulisan ini, dapat dilihat bahwa penyebab terjadinya integrasi masyarakat dalam hal ini hubungan pela antara Negeri Amahai dipulau Seram dan Negeri Ihamahu dipulau Saparua adalah peristiwa gempa bumi dan tsunami besar yang menerjang Negeri Amahai dan sekitarnya, dan kebetulan masyarakat Negeri Ihamahu juga berada disana dalam rangka mengambil kayu besi untuk proses pembuatan gedung gereja, peristiwa ini kemudian dikenal oleh orang Maluku secara luas dengan peristiwa bahaya Seram 1899. Akibat persitiwa ini masyarakat kedua negeri tersebut mengangkat sumpah dan janji pela pada Minggu, 26 Oktober 1924 dengan ikrar Sei Hale Hatu, Hatu Hale Ei, Sei Risa Sou, Sou Risa Ei. Ikatan pela ini memiliki suatu hukum yang mengikat seluruh masyarakat negeri, dan siapapun yang melanggarnya akan menerima sangksinya berupa kutukan yang mengerikan hingga kematian, hukum ini disebut sebagai hukum pela yang antara lain, tidak boleh saling mengawini (bahkan jatuh cinta sekalipun) antara masyarakat kedua negeri, harus saling membantu, tidak boleh saling curiga, marah, dendam, dan saling mempersalahkan, harus bertegur sapa saat bertemu dijalan. Hal ini, membentuk sebuah integrasi masyarakat yang unik karena hubungan ini timbul atas persitiwa bencana, yang kadang oleh sebagian orang dianggap sebagai suatu persitiwa yang merugikan, namun mereka dapat merekonstrusi ulang hubungan integrasi masyarakat ini menjadi lebih baik dan dapat dipertahankan sampai

\footnotetext{
${ }^{10}$ Ini berarti siapa yang membalikbatu, batu akan menindisdia, dan siapa yang melanggar janji, dia akan dihukum.

${ }^{11}$ Totobuang adalah alat musik pukul yang ada di Maluku, sama dengan Gamelan di Jawa.
} 
saat ini, dan selama-lamanya. Dari hubungan pela antara Negeri Amahai dan Negeri Ihamahu, kita dapat melihat dan mempelajari bahwa dalam setiap peristiwa bencana tidak selamanya memiliki dampak buruk saja tetapi juga dampak baik, yang dapat dipetik hikmahnya sebagai pedoman dimasa depan, bagai pelangi sehabis badai.

\section{UCAPAN TERIMA KASIH}

1. Prof. Drs. J. A. Pattikayhattu (Sejarawan Maluku)

2. Johan. Pattiasina, S. Pd., M. A (KAPRODI Pendidikan Sejarah, UNPATTI)

3. Bapak E. Wattimury (Narasumber/Informan)

4. Bapak S. Lernaya (Narasumber/Informan)

5. Bapak E. C. Lokollo (Narasumber/Informan)

6. Bapak T. Wattimury (Narasumber/Informan)

\section{DAFTAR PUSTAKA}

Binnendyk, E., \& Pusparani, R. (2015). Dasar-Dasar Sejarah. Pensil Komunika.

Kartodirdjo, S. (1994). Pendekatan Ilmu Sosial Dalam Metodologi Sejarah. Gramedia Pustaka Utama.

Kuntowijoyo. (1995). Pengantar Ilmu Sejarah. Yayasan Benteng Budaya.

Lokollo, J. E. (1997). Seri Budaya Pela Gandong dari Pulau Ambon. Ambon: Lembaga Kebudayaan Daerah Maluku.

Moleong, L. J. (2002). Metodologi Penelitian Kualitatif, cetakan ketujuh belas. Penerbit PT Remaja Rosdakarya, Bandung.

Notosusanto. (1979). Sejarah Demi Masa Kini. UI Press.

Parekh, B. (2008). A new politics of identity: Political principles for an interdependent world. Macmillan International Higher Education.

Pattiasina, J. (2019). Prosiding Merajut Ke-Bhineka Tunggal Ika-an Dalam Bingkai Harmonisan. BPNB Sulawesi Utara.

Pattikayhattu, J. A. (2005). Budaya Pela Dan Gandong Di Maluku Tengah. FKIP Unpatti. Undang-Undang Republik Indonesia Nomor 24 Tahun 2007 Tentang Penanggulangan Bencana

\section{Hasil Diskusi}

Tidak ada pertanyaan 